\title{
Evaluation of the Fresh and Hardened Properties of Steel Fibre Reinforced Self-Compacting Concrete Using Recycled Aggregates as a Replacement Material
}

\author{
N. Nalanth, ${ }^{1}$ P. Vincent Venkatesan, ${ }^{2}$ and M. S. Ravikumar ${ }^{3}$ \\ ${ }^{1}$ Anna University Chennai, Tamil Nadu, India \\ ${ }^{2}$ Department of Civil Engineering, Mepco Schlenk Engineering College, Tamil Nadu, India \\ ${ }^{3}$ Department of Civil Engineering, Noorul Islam University, Tamil Nadu, India
}

Correspondence should be addressed to N. Nalanth; nalanth76@gmail.com

Received 3 October 2013; Revised 23 January 2014; Accepted 8 February 2014; Published 16 March 2014

Academic Editor: Jamal Khatib

Copyright (C) 2014 N. Nalanth et al. This is an open access article distributed under the Creative Commons Attribution License, which permits unrestricted use, distribution, and reproduction in any medium, provided the original work is properly cited.

\begin{abstract}
In this world of rapid urbanization the demand for natural construction materials is increasing day by day which has created a necessity for alternative construction materials. Recycling of materials is a possible way of eradicating the acute shortage of materials. Considerable work has been done in the area of self-compacting concrete by partial replacement of coarse aggregates (CA) with recycled coarse aggregates (RCA) obtained from construction and demolition debris. The present study has been done by adding steel fibers to concrete in a view of improving the mechanical properties of SCC so that it can be applied in beam column joints. An ideal mix proportion was arrived at, as a result of repeated trials and specimens that were cast and cured. The compression, tensile, and flexural strength parameters were determined and the result has been presented. The results obtained reveal that brick bats in combination with steel fibres may be used extensively in SCC.
\end{abstract}

\section{Introduction}

Self-compacting concrete as we all know is a concrete which exhibits good flow properties, good passing ability, and segregation resistance. No vibration is required to compact the concrete since the SCC has the capability of compacting under its own weight after being placed. Also SCC effectively passes through the congested reinforcements and uniformly fills up the voids. The SCC thus obtained is dense and homogeneous and has superior surface finish [1-3]. In order to attain the above said properties, chemical admixtures like superplasticizers and viscosity modifiers are generally used. The dosage of the chemical admixtures is an important parameter which influences the fresh state properties of SCC. Many research works carried out in this area have proved that the role of chemical admixtures is inevitable in achieving good fresh state properties of SCC [4-6]. The effectiveness of high calcium fly ash for producing SCC was investigated in this work. The fresh and hardened properties of SCC using recycled aggregates by adding suitable proportion of chemical admixture and fly ash have been studied in this work [7-9]. In addition this study was carried out by adding steel fiber's to SCC.

The brief literature reviews of some of the latest studies are as follows. Reference [10] studied the fresh and hardened properties of SCC using recycled concrete aggregates as both coarse and fine aggregates states. Three series of SCC mixtures were prepared with $100 \%$ coarse recycled aggregates, and different levels of fine recycled aggregates were used to replace river sand. The cement content was kept constant for all concrete mixtures. Reference [11] studied the potential usage of RCA obtained from crushed concrete for making SCC and additionally emphasizing its ecological value. In their experiment, three types of concrete mixtures were made, where the percentage of substitution of coarse aggregate by recycled aggregate was $0 \%, 50 \%$, and $100 \%$. In the process of mixing, equal consistence of all concrete mixtures was achieved. Reference [12] determined 
the influence of different curing conditions on the mechanical performance of concrete made with coarse recycled aggregate from crushed concrete. The properties analyzed include compressive strength, split tensile strength, modulus of elasticity, and abrasion resistance. Reference [13] studied the benefits of limestone powder, basalt powder, and marble powder as partial replacement of Portland cement and being used directly in the production of SCC. The water-to-binder ratio was maintained at 0.33 for all mixture. In [14] the influence of fly ash (FA) on the properties of self-compacting concrete (SCC) is investigated. Portland cement (PC) was partially replaced with $0-80 \%$ FA. The water-to-binder ratio was maintained at 0.36 for all mixes. Properties included workability, compressive strength, ultrasonic pulse velocity $(V)$, absorption, and shrinkage. The results indicate that high volume FA can be used in SCC to produce high strength and low shrinkage. Replacing $40 \%$ of PC with FA resulted in strength of more than $65 \mathrm{~N} / \mathrm{mm}^{2}$ at 56 days. High absorption values are obtained with increasing amount of FA; however, all FA concrete exhibits absorption of less than $2 \%$. There is a systematic reduction in shrinkage as the FA content increases and at $80 \%$ FA content, the shrinkage at 56 days reduced by two-thirds compared with the control. A linear relationship exists between the 56-day shrinkage and FA content. Increasing the admixture content beyond a certain level leads to a reduction in strength and increase in absorption. The correlation between strength and absorption indicates that there is a sharp decrease in strength as absorption increases from 1 to $2 \%$. After $2 \%$ absorption, the strength reduces at a much slower rate. Reference [15] studied the effect of coarse aggregate gradation on the properties of SCC. Four SCC mixtures with A/B (size 5-10 mm coarse aggregate weight/size $1020 \mathrm{~mm}$ coarse aggregate weight) ratios $4 / 6,5 / 5$, $6 / 4$, and $7 / 3$ were prepared; the bulk density of aggregates with various $\mathrm{A} / \mathrm{B}$ ratios was investigated. The effectiveness of various types of coarse aggregates on fresh and hardened properties of SCC was investigated [16]. Five different coarse aggregate types such as basalt, marble, dolomite, limestone, and sand stone were used to produce SCC containing fly ash. The water-to-binder ratio was maintained at 0.33 for all mixtures. The objective of this paper is to study the effect of utilizing recycled coarse aggregate as partial replacement for natural coarse aggregate on the properties of SCC in fresh and hardened states. Reference [17] presents information regarding development, properties, and advantages and disadvantages of using high-strength self-consolidating concrete in the construction industry. It also presents results of a study recently completed for manufacturing economical highstrength self-consolidating concrete containing high volumes of fly ash. In this study, Portland cement was replaced by Class $\mathrm{C}$ fly ash in the range of $35-55 \%$ by the mass of cement. The results of fresh and hardened properties of concrete show that the use of high volumes of Class $\mathrm{C}$ fly ash in selfconsolidating concrete reduces the requirements for superplasticizer (HRWRA) and viscosity modifying agent (VMA) compared with the normal dosage for such admixtures in self-consolidating concrete. The results further indicate that economical self-consolidating concrete with 28 -day strengths up to $62 \mathrm{MPa}$ can be made using high volumes of fly ash. Such concretes can be used for a wide range of applications from cast-in-place to precast concrete construction.

\section{Materials}

All the materials used for this study were obtained locally. Ordinary Portland cement (53 grades) was used for this experimental investigation. Cement was partially replaced with Class C fly ash obtained from Tuticorin Thermal Power Station, Tamil Nadu, India. The purpose of using high volumes of fly ash in SCC is to obtain improved workability properties. Previous studies show that the use of mineral admixtures such as fly ash could increase the slump of the concrete mixture without increasing its cost and also it improves the rheological properties and reduces the cracking potential of concrete. Locally available sand with $4.75 \mathrm{~mm}$ maximum size was used as fine aggregate and crushed stone with $12-20 \mathrm{~mm}$ size was used as coarse aggregate. Coarse aggregates were partially replaced with brick bats. Recycled aggregates were obtained from a demolished residential building in the adjacent locality, were treated as construction waste, and were crushed to obtain suitable sizes for being used in SCC. The broken brick bat passing through $20 \mathrm{~mm}$ IS sieve was used. Potable water, that is, water free from impurities, was used for the mixes. Steel fibers of aspect ratio 75 were added in suitable proportion to SCC. High performance polycarboxylate-based superplasticizer was used to achieve good workability. A low water-to-cement ratio (w/c) of mortar and concrete was adopted to achieve improved strength and durability. The use of superplasticizer allows reducing $\mathrm{w} / \mathrm{c}$ of mortar and concrete. The high flow ability is achieved by using superplasticizer, while stability against segregation is achieved either by using a large quantity of fine materials or by using appropriate viscosity modifying agent (VMA) [18-22]. All preliminary tests on materials were conducted and the results have been presented. The properties of 53grade OPC have been given in Table 1. Figure 1 represents the particle size distribution curve of both fine aggregate and coarse aggregate. The chemical composition of Class $\mathrm{C}$ fly ash has been given in Table 2. The mix proportion adopted for the experimental investigation is given in Table 3 and the test results are given in Table 4.

\section{Mixture Proportion}

Two series of SCC mixes were employed to study the fresh and hardened properties of SCC. The first series (BB1, BB2, and $\mathrm{BB} 3$ ) involved the partial replacement of CA with RA obtained by breaking down Class I bricks to a size of the range of $10-12 \mathrm{~mm}$ in three proportions of the order of $30 \%$, $40 \%$, and $50 \%$, respectively. In the second series (SFBB1, SFBB2, and SFBB3) in addition to RA, steel fibers were added in the ratio of $0.5 \%, 0.75 \%$, and $1 \%$, respectively. The ideal proportion in both of the series including that of the control specimen was obtained as a result of repeated trials by suitably combining the FA and CA fractions so as to meet the requirements of SCC. 
TABLE 1: Results of test on cement.

\begin{tabular}{ccccccc}
\hline \multirow{2}{*}{ Cement } & \multirow{2}{*}{ Fineness $\mathrm{m}^{2} / \mathrm{kg}$} & \multicolumn{2}{c}{ Setting time $(\mathrm{min})$} & \multicolumn{2}{c}{ Soundness $(\mathrm{mm})$} & \multicolumn{3}{c}{${\text { Compressive strength }\left(\mathrm{N} / \mathrm{mm}^{2}\right)}^{2}$} \\
& & Initial $(\mathrm{min})$ & Final $(\max )$ & Le Chatelier $(\mathrm{mm})$ & 7 days & 28 days \\
\hline OPC 53 & 228 & 30 & 600 & 9.2 & 36 & 53 \\
\hline
\end{tabular}

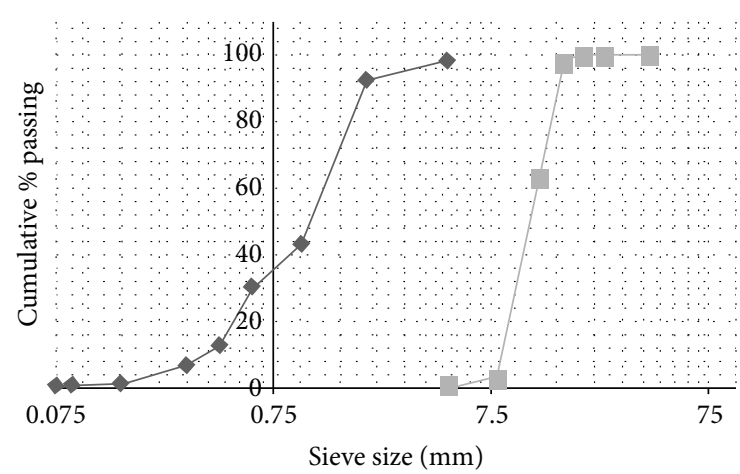

$\rightarrow$ Fine aggregate

$\rightarrow-$ Coarse aggregate

Figure 1: Particle size distribution of fine aggregate and coarse aggregate.

TABLE 2: Chemical composition of Class C fly ash.

\begin{tabular}{lc}
\hline Chemical compound & Percentage \\
\hline $\mathrm{SiO}$ & 39.90 \\
$\mathrm{Al}_{2} \mathrm{O}_{3}$ & 16.70 \\
$\mathrm{Fe}_{2} \mathrm{O}_{3}$ & 5.80 \\
$\mathrm{CaO}$ & 24.30 \\
$\mathrm{MgO}$ & 4.60 \\
$\mathrm{SO}_{3}$ & 3.30 \\
$\mathrm{Na}_{2} \mathrm{O}$ and $\mathrm{K}_{2} \mathrm{O}$ & 1.30 \\
\hline
\end{tabular}

\section{Experimental Analysis}

Fresh state tests like slump flow, L-box, J-ring, and V-funnel tests were conducted. Cubes, beams, and cylinders were cast and tested for mechanical properties after 7 days, 14 days, and 28 days with adequate water curing. Hardened test on specimens was conducted to determine the compression strength, split tensile strength, and flexural strength. The following preliminary tests were conducted on the cement: fineness test, consistency test, initial setting time test, and final setting time test. Tests like sieve analysis test, specific gravity test, and bulk density test were conducted on fine aggregates (FA) as well as coarse aggregates (CA). Fresh state tests on SCC, like slump flow test, L-box test, V-funnel test, J-ring test, and so forth, were conducted. The slump flow test aims at investigating the filling ability of the SCC. It measures two parameters, flow spread and flow time. The former indicates the free unrestricted deformation and the latter indicates the rate of deformation within a defined flow distance. The L-box test as shown in Figure 2 aims at investigating the passing ability of SCC [23, 24]. The difference in level between the beginning and end of the box

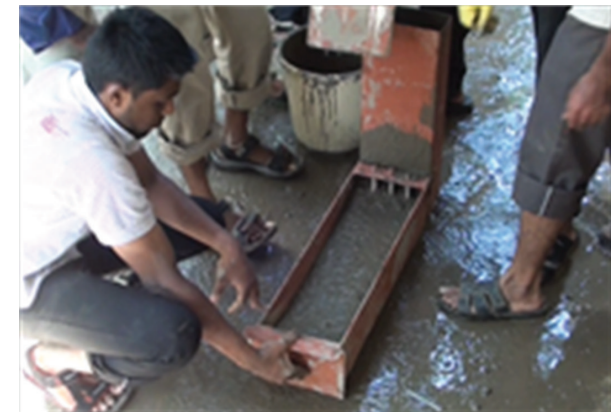

Figure 2: L-box test.

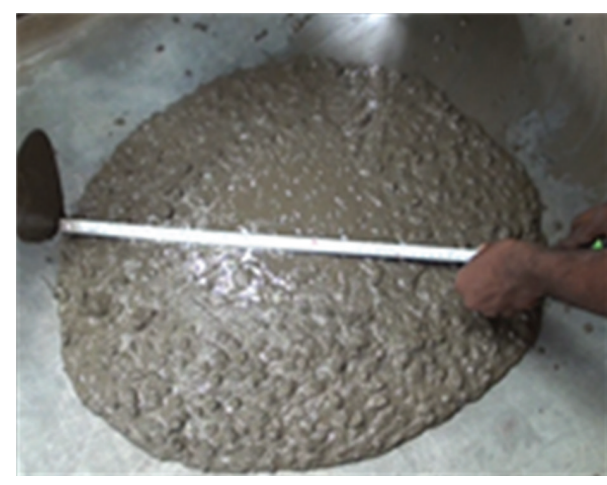

FIgURE 3: Slump flow test. and the time required to reach the final configuration was measured.

The slump flow test as shown in Figure 3 is meant for determining the flow ability of SCC. The spread diameter is an indicator of the above said parameter. The J-ring test aims at investigating both the filling ability and passing ability of SCC. It can also be used to investigate the resistance of SCC to segregation by comparing test results from two different portions of the sample. The J-ring test measures three parameters: flow spread, flow time, and blocking step.

The J-ring test is represented in Figure 4. The J-ring flow spread indicates the restricted deformability of SCC due to blocking effect of reinforcement bars and flow time indicates the rate of deformation within a defined flow distance. The blocking step quantifies the effect of blocking. The V-funnel flow time is the period a defined volume of SCC needs to pass a narrow opening and gives an indication of the filling ability of SCC provided that blocking and/or segregation do not take place: the flow time of the $\mathrm{V}$-funnel test is to some degree related to plastic viscosity $[25,26]$. 
TABLE 3: Mix proportion.

\begin{tabular}{lcccccccccc}
\hline Sl. no. & Mix ID & Steel fibers \% & $\begin{array}{c}\text { Cement } \\
\left(\mathrm{kg} / \mathrm{m}^{3}\right)\end{array}$ & $\begin{array}{c}\text { Fly ash } \\
\left(\mathrm{kg} / \mathrm{m}^{3}\right)\end{array}$ & $\begin{array}{c}\text { Water } \\
\left(1 / \mathrm{m}^{3}\right)\end{array}$ & $\begin{array}{c}\text { Water to } \\
\text { binder ratio }\end{array}$ & $\begin{array}{c}\text { FA } \\
\left(\mathrm{kg} / \mathrm{m}^{3}\right)\end{array}$ & $\begin{array}{c}\text { CA } \\
\left(\mathrm{kg} / \mathrm{m}^{3}\right)\end{array}$ & $\begin{array}{c}\text { Brick bats } \\
\left(\mathrm{kg} / \mathrm{m}^{3}\right)\end{array}$ & $\begin{array}{c}\text { SP } \\
\left(\mathrm{l} / \mathrm{m}^{3}\right)\end{array}$ \\
\hline 1 & NSCC & - & 315 & 135 & 256.5 & 0.57 & 919.00 & 649 & - & 9.5 \\
2 & BB-1 & - & 315 & 135 & 256.5 & 0.57 & 918.75 & 454.13 & 194.63 & 8 \\
3 & BB-2 & - & 315 & 135 & 256.5 & 0.57 & 918.75 & 389.25 & 259.50 & 8.5 \\
4 & BB-3 & - & 315 & 135 & 256.5 & 0.57 & 918.75 & 324.36 & 324.36 & 9.5 \\
5 & BBSF-1 & 0.5 & 315 & 135 & 256.5 & 0.57 & 918.75 & 454.13 & 194.63 & 8 \\
6 & BBSF-2 & 0.75 & 315 & 135 & 256.5 & 0.57 & 918.75 & 389.25 & 259.50 & 8.5 \\
7 & BBSF-3 & 1.0 & 315 & 135 & 256.5 & 0.57 & 918.75 & 324.36 & 324.36 & 9.5 \\
\hline
\end{tabular}

FA: fine aggregate; CA: coarse aggregate; RA: recycled aggregate.

TABLE 4: Results of test conducted on concrete.

\begin{tabular}{|c|c|c|c|c|c|c|c|c|c|}
\hline \multirow{2}{*}{ Mix ID } & \multicolumn{3}{|c|}{ Compressive strength $\left(\mathrm{N} / \mathrm{mm}^{2}\right)$} & \multicolumn{3}{|c|}{ Flexural strength $\left(\mathrm{N} / \mathrm{mm}^{2}\right)$} & \multicolumn{3}{|c|}{ Split tensile strength $\left(\mathrm{N} / \mathrm{mm}^{2}\right)$} \\
\hline & 7 days & 14 days & 28 days & 7 days & 14 days & 28 days & 7 days & 14 days & 28 days \\
\hline NSCC & 18.34 & 24.72 & 32.45 & 2.51 & 3.29 & 3.53 & 1.95 & 2.65 & 2.99 \\
\hline BB1 & 17.75 & 21.12 & 28.32 & 2.34 & 2.56 & 3.24 & 1.88 & 2.43 & 2.85 \\
\hline BB2 & 14.71 & 18.89 & 23.14 & 2.25 & 2.55 & 3.05 & 1.77 & 2.16 & 2.77 \\
\hline BB3 & 11.32 & 15.56 & 21.11 & 2.2 & 2.85 & 2.86 & 1.68 & 2.06 & 2.66 \\
\hline BBSF1 & 16.89 & 22.30 & 29.50 & 2.56 & 2.80 & 3.20 & 1.98 & 2.48 & 2.99 \\
\hline BBSF2 & 16.76 & 20.24 & 25.45 & 2.42 & 2.78 & 3.35 & 1.88 & 2.25 & 2.94 \\
\hline BBSF3 & 13.25 & 17.37 & 23.22 & 2.54 & 2.96 & 3.50 & 1.96 & 2.45 & 2.95 \\
\hline
\end{tabular}

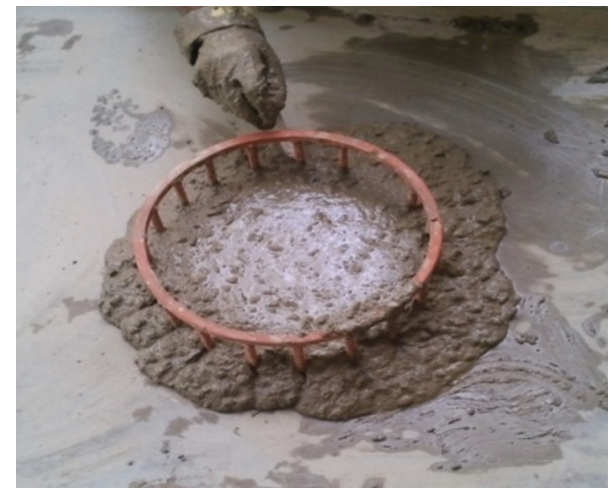

FIGURE 4: J-ring test.

TABLE 5: Results of fresh state tests on SCC.

\begin{tabular}{lccccc}
\hline Mixture & \multicolumn{2}{c}{ Slump flow } & $\begin{array}{c}\text { J-ring } \\
(\mathrm{mm})\end{array}$ & $\begin{array}{c}\text { L-box } \\
(\mathrm{mm})\end{array}$ & $\begin{array}{c}\text { V-funnel } \\
(\mathrm{Sec})\end{array}$ \\
\hline NSCC & 740 & 2 & 7.3 & 1.0 & 8.31 \\
BB1 & 731 & 2.18 & 7.5 & 0.95 & 8.96 \\
BB2 & 727 & 2.95 & 7.9 & 0.91 & 9.13 \\
BB3 & 723 & 3.05 & 8.3 & 0.89 & 9.47 \\
SFBB1 & 721 & 3.61 & 8.8 & 0.86 & 10.22 \\
SFBB2 & 716 & 3.85 & 9.4 & 0.84 & 10.89 \\
SFBB3 & 704 & 4.09 & 9.8 & 0.83 & 11.07 \\
\hline
\end{tabular}

\section{Results and Discussion}

From the detailed study and analysis of the experimental test results obtained by conducting fresh state tests like slump flow test, L-box test, V-funnel test, J-ring test, and so forth, it is evident that the slump flow diameter decreased with the increase in the replacement proportion of RA but the slump flow diameter was well in the range of SCC requirement $(650 \mathrm{~mm}-800 \mathrm{~mm})$. There was a further more reduction in slump flow diameter due to the addition of steel fibres but the flow values were quite in range. The L-box test, V-funnel test, and J-ring test results as given in Table 5 reveal acceptable values of passing ability and filling ability.

Flexural strength test, split tensile strength test, and compressive strength test results are represented in Figures 5, 6 , and 7. The use of RA resulted in reduced flexural strength, split tensile strength, and compressive strength.

However, the addition of steel fibers resulted in increase in the flexural strength and split tensile strength.

It was found that the addition of $30 \%$ brick bats and $1 \%$ steel fiber yielded a compressive strength of $30.11 \mathrm{~N} / \mathrm{mm}^{2}$ and the corresponding mixture proportions were considered as the ideal mix proportion. Moreover, the addition of steel fibers reduced the crack width considerably. Also it was observed that due to adequate curing the problem of cracks due to shrinkage was totally eliminated. It was observed that all the constituent materials were spread uniformly in the concrete matrix including the steel fibers. 


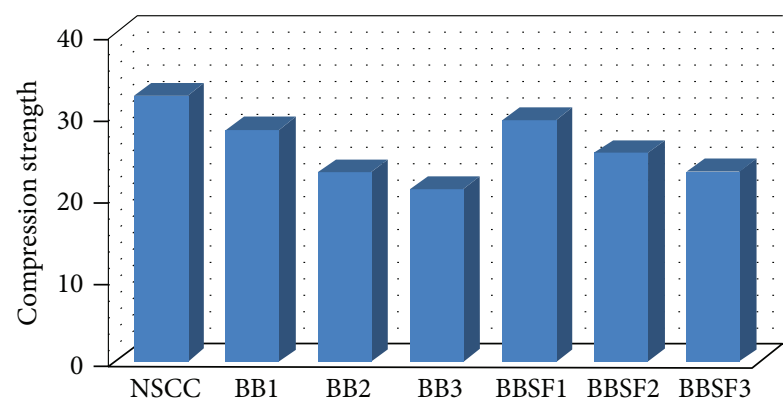

Figure 5: Comparison of the compressive strength.

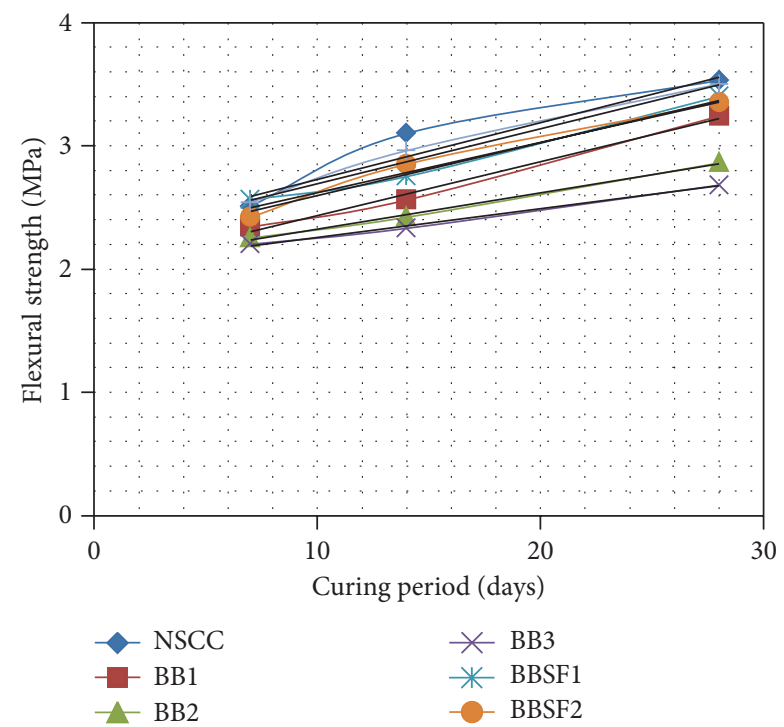

FIGURE 6: Comparison of the flexural strength.

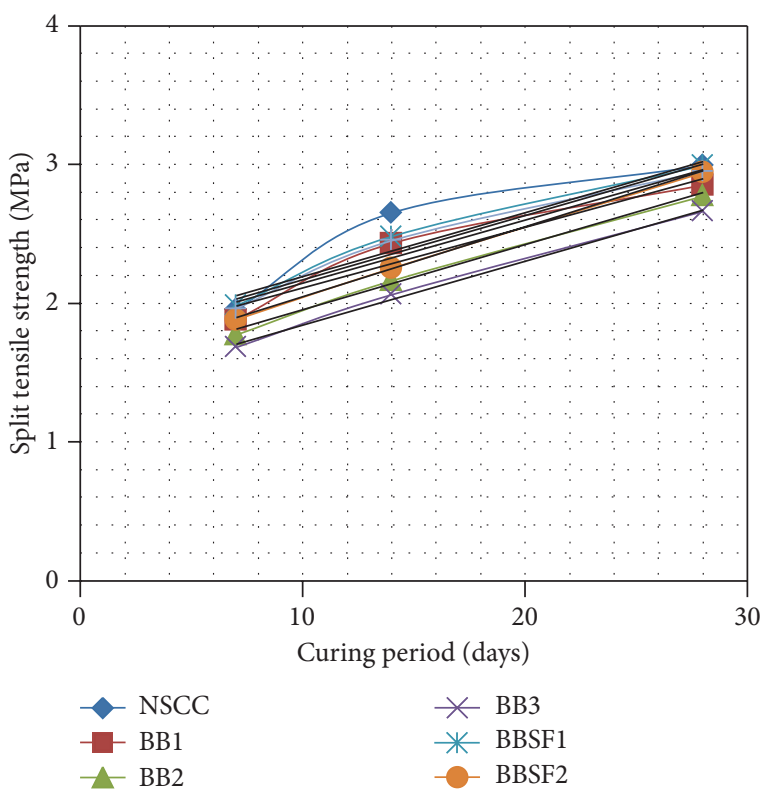

Figure 7: Comparison of the split tensile strength.

\section{Conclusions}

The recycled aggregates show higher water absorption compared with conventional normal aggregates and have low specific gravity. The test result indicates that in 28-day test SCC achieves required compression strength at 30\% replacement with recycled aggregates. The 28-day flexural strength of SCC obtained from experimental investigation is less in all the replacement ratios of recycled aggregates. The test result indicates that the compressive, flexural, and split tensile strengths of SCC decrease with the increase in the amount of recycled aggregates. The investigation gives scope for further testing of concrete elements like beams, columns, beam column joints, and other structural elements using the ideal mixture proportion obtained from this experimental investigation.

\section{Conflict of Interests}

The authors declare that there is no conflict of interests regarding the publishing of this paper.

\section{References}

[1] "EFNARC specification and guidelines for self-compacting concrete," 2002.

[2] H. Okamura and M. Ouchi, "Self-compacting concrete," Journal of Advanced Concrete Technology, vol. 1, no. 1, pp. 5-15, 2003.

[3] F. de Larrard, C. F. Ferraris, and T. Sedran, "Fresh concrete: a Herschel-Bulkley material," Materials and Structures, vol. 31, no. 211, pp. 494-498, 1996.

[4] B. Li, J. Wang, and M. Zhou, "Effect of limestone fines content in manufactured sand on durability of low- and high-strength concretes," Construction and Building Materials, vol. 23, no. 8, pp. 2846-2850, 2009.

[5] V. Corinaldesi and G. Moriconi, "Influence of mineral additions on the performance of $100 \%$ recycled aggregate concrete," Construction and Building Materials, vol. 23, no. 8, pp. 28692876, 2009.

[6] Z. Grdic, G. Topličić-Ćurčić, and I. Despotović, "Properties of self-compacting concrete with different type of additives," Facta Universitatis, vol. 6, no. 2, pp. 173-177, 2008.

[7] P. Billberg, "Fine mortar rheology in mix design of SCC," in Proceedings of the 1st International RILEM Symposium on SelfCompacting Concrete, A. Skarendahl and O. Petersson, Eds., pp. 47-58, Stockholm, Sweden, 1999.

[8] M. Emborg, "Rheology tests for self-compacting concretehow useful are they for the design of concrete mix for full scale production?" in Proceedings of the 1st International RILEM Symposium on Self-Compacting Concrete, A. Skarendahl and O. Petersson, Eds., pp. 95-105, Stockholm, Sweden, 1999.

[9] A. W. Saak, H. M. Jennings, and S. P. Shah, "Characterization of the rheological properties of cement paste for use in selfcompacting concrete," in Proceedings of the 1st International RILEM Symposium on Self-Compacting Concrete, A. Skarendahl and O. Petersson, Eds., pp. 83-93, Stockholm, Sweden, 1999.

[10] Z. J. Grdic, G. A. Toplicic-Curcic, I. M. Despotovic, and N. S. Ristic, "Properties of self-compacting concrete prepared with coarse recycled concrete aggregate," Construction and Building Materials, vol. 24, no. 7, pp. 1129-1133, 2010. 
[11] N. Fonseca, J. de Brito, and L. Evangelista, "The influence of curing conditions on the mechanical performance of concrete made with recycled concrete waste," Cement and Concrete Composites, vol. 33, no. 6, pp. 637-643, 2011.

[12] M. Uysal and K. Yilmaz, "Effect of mineral admixtures on properties of self-compacting concrete," Cement and Concrete Composites, vol. 33, no. 7, pp. 771-776, 2011.

[13] H. Zhao, W. Sun, X. Wu, and B. Gao, "The effect of coarse aggregate gradation on the properties of self-compacting concrete," Materials and Design, vol. 40, pp. 109-116, 2012.

[14] J. M. Khatib, "Performance of self-compacting concrete containing fly ash," Construction and Building Materials, vol. 22, no. 9, pp. 1963-1971, 2008.

[15] M. Uysal, "The influence of coarse aggregate type on mechanical properties of fly ash additive self-compacting concrete," Construction and Building Materials, vol. 37, pp. 533-540, 2012.

[16] J.-Y. Petit, E. Wirquin, Y. Vanhove, and K. Khayat, "Yield stress and viscosity equations for mortars and self-consolidating concrete," Cement and Concrete Research, vol. 37, no. 5, pp. 655670, 2007.

[17] T. R. Naik, R. Kumar, B. W. Ramme, and F. Canpolat, "Development of high-strength, economical self-consolidating concrete," Construction and Building Materials, vol. 30, pp. 463-469, 2012.

[18] M. R. Geiker, M. Brandl, L. N. Thrane, D. H. Bager, and O. Wallevik, "The effect of measuring procedure on the apparent rheological properties of self-compacting concrete," Cement and Concrete Research, vol. 32, no. 11, pp. 1791-1795, 2002.

[19] L. D. Schwartzentruber, R. le Roy, and J. Cordin, "Rheological behaviour of fresh cement pastes formulated from a Self Compacting Concrete (SCC)," Cement and Concrete Research, vol. 36, no. 7, pp. 1203-1213, 2006.

[20] N. Su, K.-C. Hsu, and H.-W. Chai, "A simple mix design method for self-compacting concrete," Cement and Concrete Research, vol. 31, no. 12, pp. 1799-1807, 2001.

[21] S. Nunes, H. Figueiras, P. Milheiro Oliveira, J. S. Coutinho, and J. Figueiras, "A methodology to assess robustness of SCC mixtures," Cement and Concrete Research, vol. 36, no. 12, pp. 2115-2122, 2006.

[22] J. Jin, Properties of mortar for self-compacting concrete [Ph.D. thesis], University College London, London, UK, 2002.

[23] "Testing fresh concrete-part 8: self-compacting concreteslump-flow test," EN 12350-8, 2007.

[24] “Testing fresh concrete-part 9: self-compacting concrete-Vfunnel test," EN 12350-9, 2007.

[25] "Testing fresh concrete-part 12: self-compacting concreteJring test," EN 12350-12, 2007.

[26] "Testing fresh concrete-part 11:self-compacting concretesieve segregation test," EN 12350-11, 2007. 

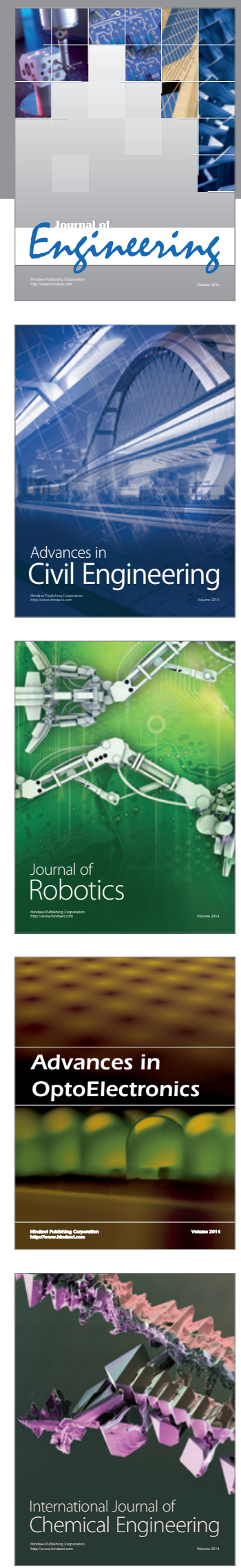

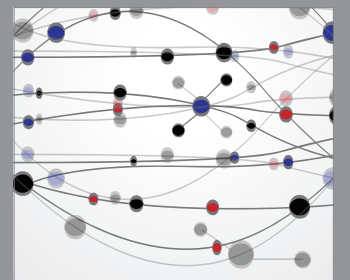

The Scientific World Journal
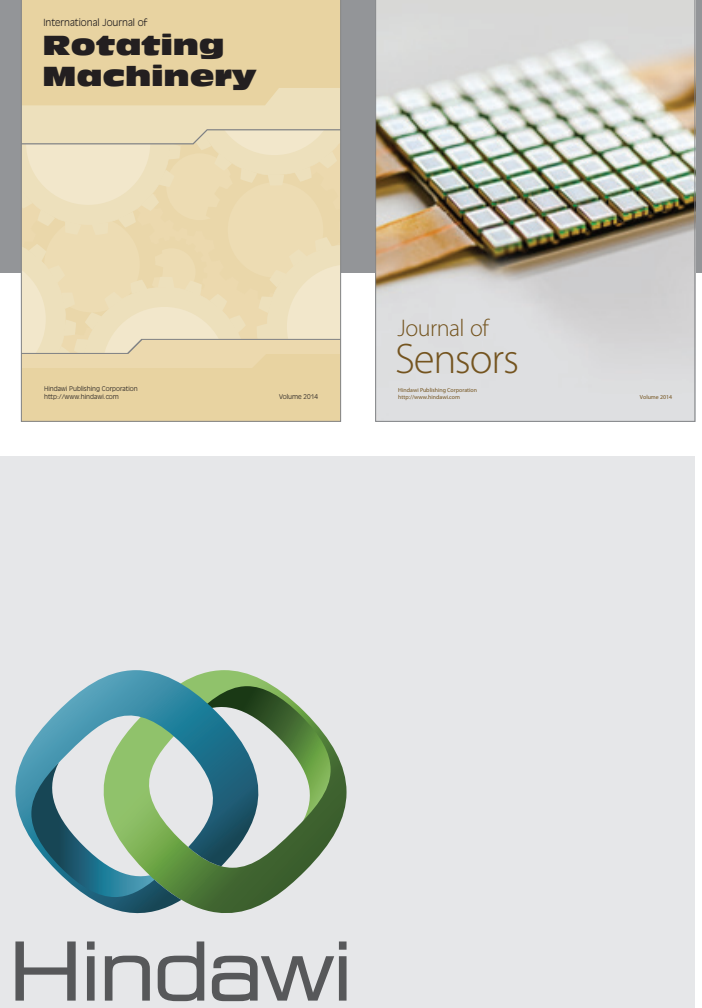

Submit your manuscripts at http://www.hindawi.com
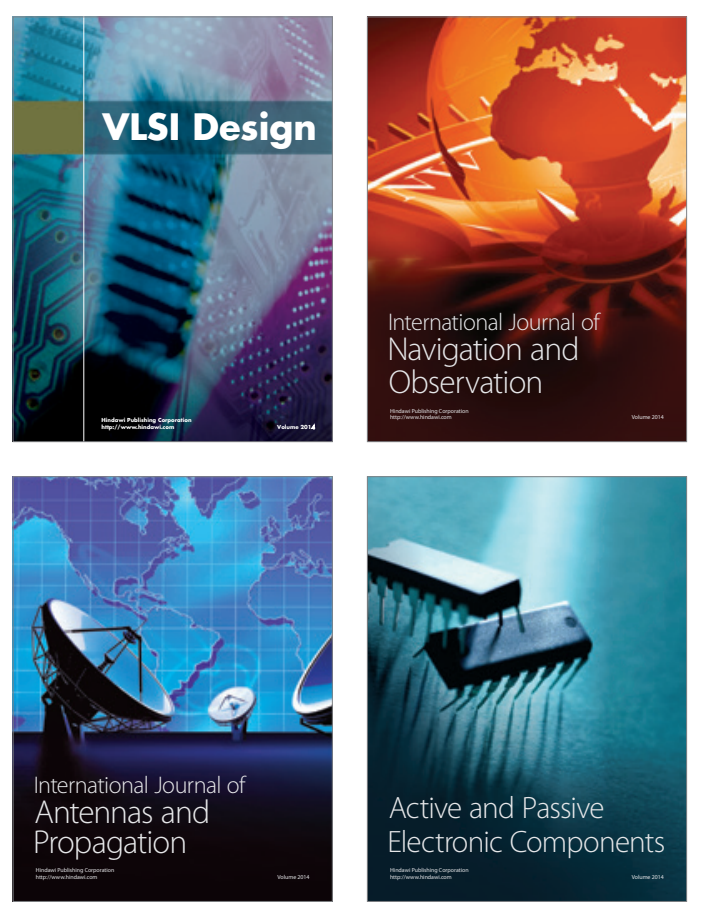
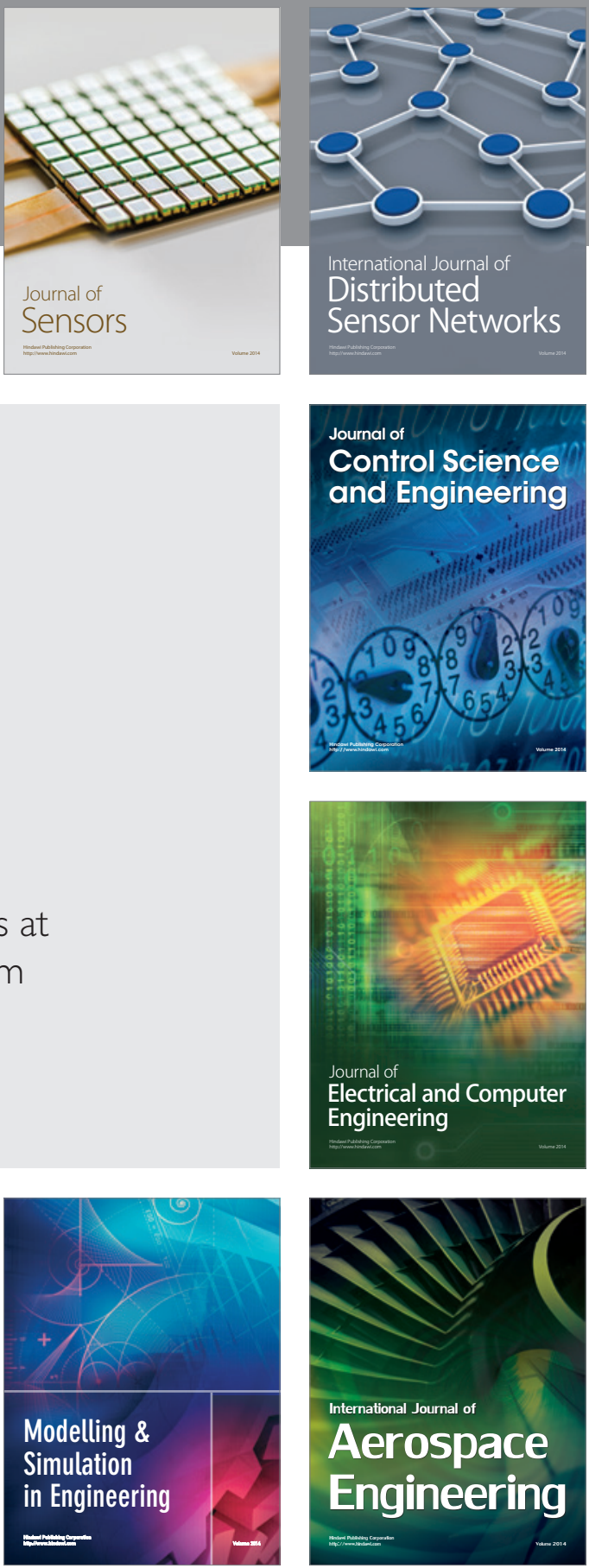

Journal of

Control Science

and Engineering
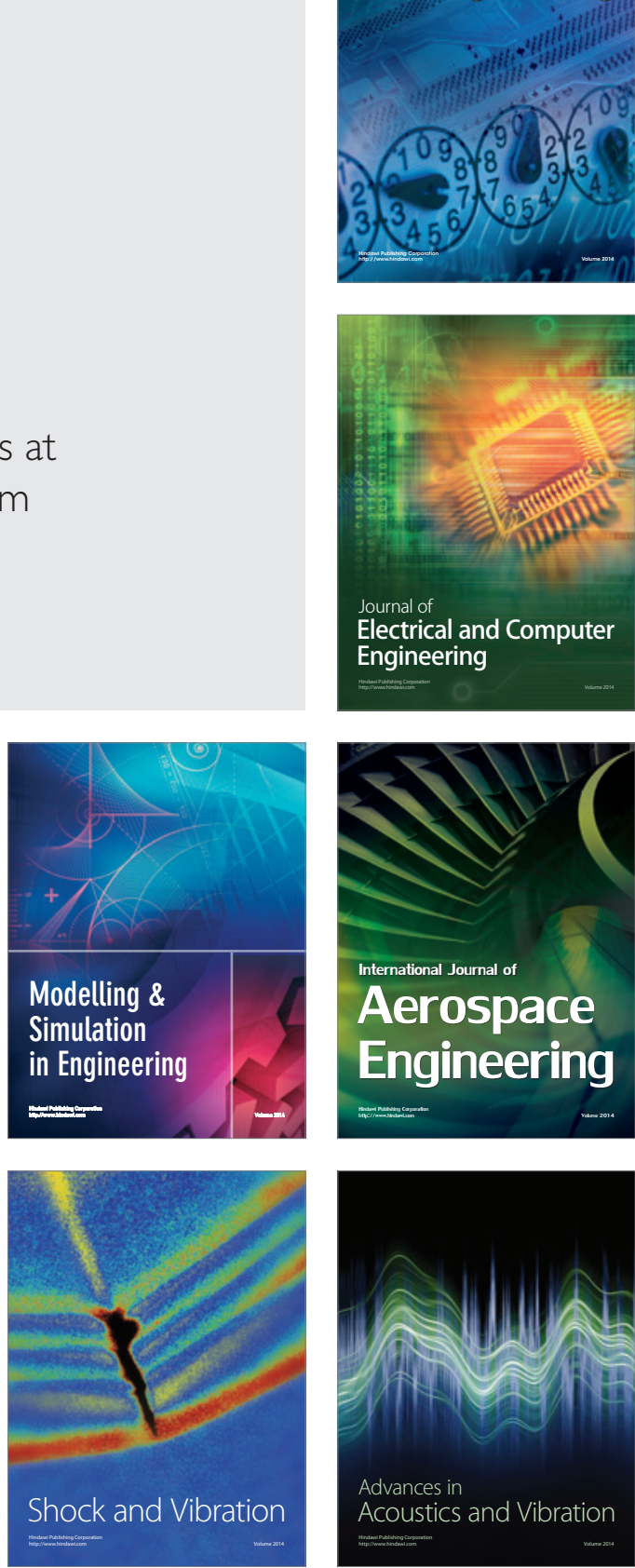